Рекомендована д. хім. наук, профр. В. С. Матійчук

УДК 615.012.1:547.789/.793

DOI 10.11603/2312-0967.2017.3.8037

\title{
СИНТЕЗ ТА ДОСЛІДЖЕННЯ АНТИТРИПАНОСОМНОї АКТИВНОСТІ НОВИХ 5-ІЛІДЕН-2-(1,3,4-ТІАДІАЗОЛ-2-ІЛ)ІМІНОТІАЗОЛІДИН-4-ОНІВ
}

\author{
() М. І. Лелюх ${ }^{1}$, Б. С. Зіменковський ${ }^{1}$, І. Л. Демчук ${ }^{1}$, Філіп Грельє ${ }^{2}$, Р. Б. Лесик ${ }^{1}$ \\ Львівський національний медичний університет імені Данила Галицького ${ }^{1}$ \\ Національний музей природничої історії, 2 Париж, Франція \\ lelyukh.m@gmail.com \\ dr_r_lesyk@org.Iviv.net
}

\begin{abstract}
Мета роботи. На основі реакцій гетероциклізації та Кньовенагеля здійснити синтез нових тіадіазоло-2імінотіазолідин-4-онів та їх 5-ариліденпохідних для скринінгу антитрипаносомної активності.

Матеріали і методи. Органічний синтез, спектроскопія ЯМР, елементний аналіз, фрармакологічний скринінг. Результати й обговорення. Циклізацією $N$-(1,3,4-тіадіазол-2-іл)заміщених 2-хлороацетамідів під дією амонію тіоціанату в середовищі ацетону синтезовано серію нових похідних 2-імінотіазолідин-4-ону. Наявність метиленактивної групи в положенні 5 тіазолідинового циклу отриманих 2-(1,3,4-тіадіазол-2-іл)імінотіазолідин-4онів дозволила провести їх подальшу модисрікацію в умовах реакції Кньовенагеля з різноманітними арил(гетерил) карбальдегідами, ізатином або похідними коричного альдегіду з утворенням серій відповідних 5-арил(гетерил) іліден- та 5-ізатин(3-сренілпропен)іліденпохідних як потенційних антитрипаносомних агентів. Структуру синтезованих сполук підтверджено елементним аналізом та спектроскопією ПМР.

Висновки. Результати скринінгу антитрипаносомної активності in vitro синтезованих сполук на штамі Trypanosoma brucei gambiense (TBG) дозволили ідентифрікувати чотири високоактивні сполуки, які зі значеннями $\mathrm{IC}_{50}$ в межах 7,3-12,8 мкМ володіли суттєвим трипаноцидним ефектом.
\end{abstract}

Ключові слова: 2-імінотіазолідин-4-они; 1,3,4-тіадіазоли; гетероциклізація; аміно-імінна таутомерія; конденсація Кньовенагеля; E/Z-ізомерія; спектральні характеристики; антитрипаносомна активність.

Вступ. Синтез нових похідних на основі «привілейованих» гетероциклів, зокрема 4-тіазолідинону, є обґрунтованим та перспективним в плані пошуку високоактивних хіміотерапевтичних агентів. Перспективним в зазначеному контексті $€$ поєднання 4-тіазолідинонового скафролду з іншими гетероциклами, зокрема 1,3,4-тіадіазольним, котрий є відомим фрармакофорним фррагментом і володіє встановленим різностороннім фрармакологічним потенціалом, а також широкими можливостями в плані хімічної модифрікації. Серед неконденсованих 4-тіазолідинон-тіадіазолів ідентисіковані сполуки з протипухлинною [1], антибактеріальною [2, 3], антиконвульсантною [4, 5], антивірусною [6], антиоксидантною [1] анальгетичною [7], гіпоглікемічною та гіполіпідемічною [8] діями. Важливо відзначити, що поєднання ядра 1,3,4-тіадіазолу 3 різними гетероциклічними фррагментами в ряді випадків супроводжувалось виникненням синергічного ефекту [9-11].

Матеріали і методи. Синтетична частина роботи полягала у використанні 5-заміщених 2-аміно-1,3,4тіадіазолів, одержаних за відомими методиками [12, 13] в реакціях $N$-ацилювання та гетероциклізації. Синтетичні дослідження проведені з використанням реактивів компаній «Merck» (Дармштадт, Німеччина) та «Sigma-Aldrich» (Miccyрi, США). Спектри ПМР знімались на приладі Varian Gemini 400, використовуючи DMSO-d як розчинник та тетраметилсилан (TMC) як внутрішній стандарт. Температури плавлення визначали на поляризаційному мікроскопі «NAGEMA-K8», спорядженому нагрівальним столиком «Boetius», за допомогою цифрового термометра «Ama-digit ad 14 th» при швидкості нагрівання 4ㄷ/хв. Дані елементного аналізу на вміст Нітрогену та Сульфруру відповідають вирахуваним ( $\pm 0,3$ \%).

Вивчення антитрипаносомної активності відібраних сполук проводили в Національному музеї природничої історії (Франція) під керівництвом профресора Філіпа Грельє (Philippe Grellier). In vitro дослідження здійснювали на штамі Trypanosoma brucei gambiense TBG і полягали у визначенні інгібуючої

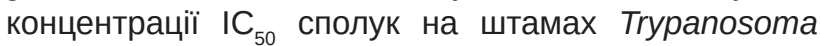
brucei gambiense (TBG) [14]. Експеримент проводився на 96-лункових мікропластинах 3 культуральним середовищем HMI9 та штамом паразита в концентрації 10-5 клітин/мл при дії досліджуваних сполук у фріксованих концентраціях 50, 10 та 1 мкг/мл. За негативний контроль обрано лунки з розчином ДМСО, середовищем та клітинами паразитів. Як препарат

ISSN 2312-0967. Pharmaceutical review. 2017. № 3 
Синтез біологічно активних сполук

Synthesis of biologically active compounds

порівняння використано пентамідин. Пластини інкубувалися при $37^{\circ} \mathrm{C}$ в атмоссрері $5 \% \mathrm{CO}_{2}$ протягом 24 год 3 наступним додаванням 20 мкл барвника Alamar Blue. Після 4-годинного інкубування вимірювали фрлуоресценцію на приладі Microplate fluorescence reader FL600. Відсотки росту паразитів визначалися за рівнем фрлуоресценції барвника Alamar Blue, a IC - за дозозалежною кривою відсоткового росту паразитів від концентрації сполук.

Результати й обговорення. В результаті ацилювання 5-етил- та 5-алілсульфаніл-2-аміно-1,3,4тіадіазолу хлороацетилхлоридом в середовищі діоксану в присутності еквімолярної кількості тріетиламіну одержано відповідні 2-хлоро-N-(5етил(алілмеркапто)-1,3,4-тіадіазол-2-іл)ацетаміди 1a-b. Для подальшого синтезу неконденсованих похідних 2-імінотіазолідин-4-ону обрано зручний та еорективний метод, що грунтується на взаємодії $N$-заміщених 2-хлороацетамідів з тіоціанатами [15]. Як відомо, така реакція не зупиняється на стадії нуклеофільного заміщення, а проходить як спонтанна гетероциклізація з утворенням 4-тіазолідонового циклу і супроводжується міграцією замісника 3 положення 3 в положення 2 (перегрупування Дімрота) [16], що є характерним для амідинових систем, зокрема і циклічних п'ятичленних. Враховуючи наведене, в результаті нагрівання сполук 1a-b 3 двократним надлишком тіоціанату амонію в середовищі ацетону одержано відповідні 5-незаміщені 2-(1,3,4-тіадіазол2-іл)-імінотіазолідин-4-они (сполук 2a-b).

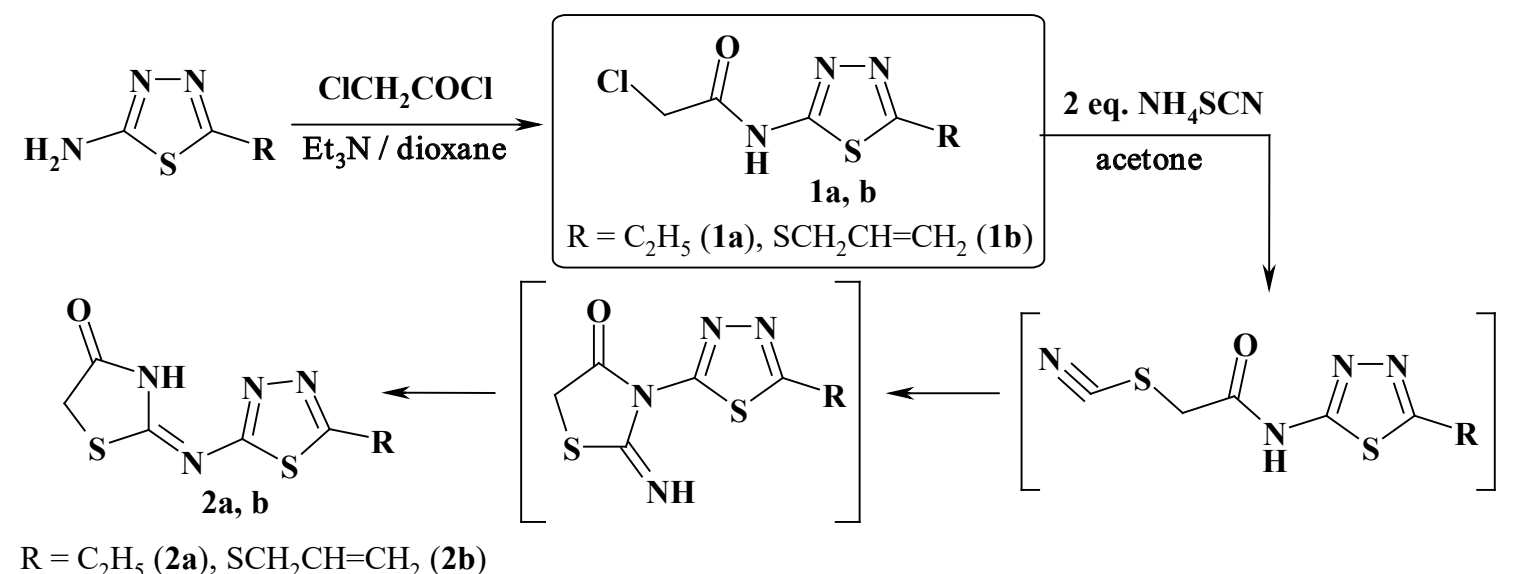

Отримані похідні 2a-b використано в якості метиленактивних сполук у реакції Кньовенагеля 3 похідними бензальдегіду, тіофен-2-карбальдегідом, піридин-3-карбальдегідом, ізатином та похідними ко-

ричного альдегіду в середовищі оцтової кислоти і присутності еквімолярної кількості ацетату натрію 3 утворенням серії 5-іліденпохідних 3a-d, 4a-c, 5a-b та 6a-b.<smiles>[Y7]C=C1SC(=Nc2nnc([R])s2)NC1=O</smiles>

$\mathrm{R}^{1}=\mathrm{C}_{2} \mathrm{H}_{5}, \mathrm{Ar}=4-\mathrm{Br}_{-} \mathrm{C}_{6} \mathrm{H}_{4}(\mathbf{3 a})$,

$4-\mathrm{N}\left(\mathrm{CH}_{3}\right)_{2}-\mathrm{C}_{6} \mathrm{H}_{4}(\mathbf{3 b})$

$\mathrm{R}^{1}=\mathrm{SCH}_{2} \mathrm{CH}=\mathrm{CH}_{2}, \mathrm{Ar}=4-\mathrm{OH}-\mathrm{C}_{6} \mathrm{H}_{4}(3 \mathrm{c})$

$4-\mathrm{CH}_{3} \mathrm{O}-\mathrm{C}_{6} \mathrm{H}_{4}(\mathbf{3 d})$<smiles>[R]c1nnc(N=C2CCC(=O)N2)s1</smiles>

Het $=$ thiophen-2-yl, $\mathrm{R}^{1}=\mathrm{C}_{2} \mathrm{H}_{5}(\mathbf{4 a})$,

$\mathrm{SCH}_{2} \mathrm{CH}=\mathrm{CH}_{2}(\mathbf{4 b})$

Het $=$ pyridin-3-yl, $\mathrm{R}^{1}=\mathrm{C}_{2} \mathrm{H}_{5}(\mathbf{4 c})$

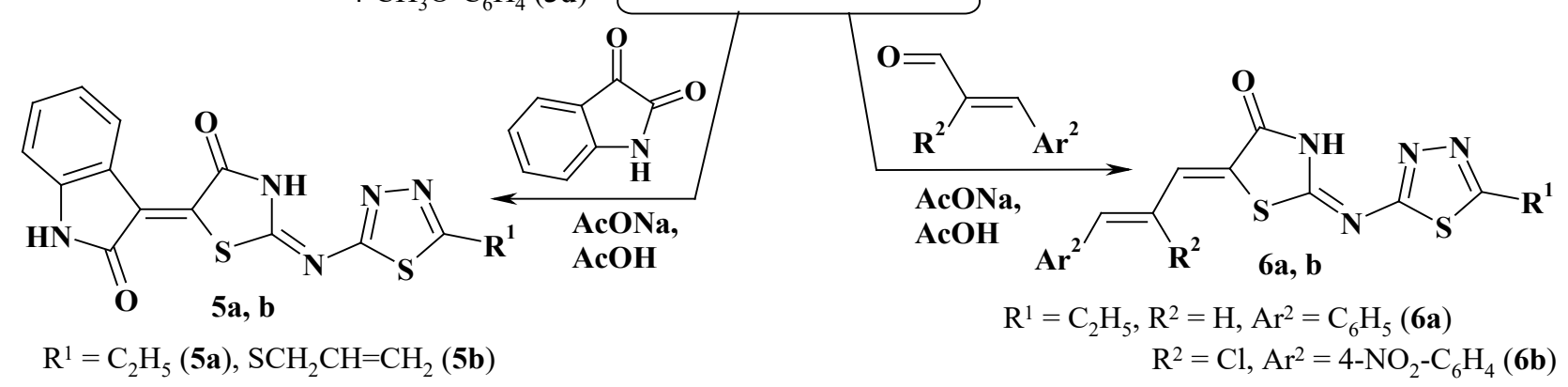

ISSN 2312-0967. Фармацевтичний часопис. 2017. № 3 
Структура синтезованих сполук підтверджена спектрами ПМР, характеристики яких наведені в експериментальній частині. У спектрах ПМР 5-незаміщених 2-імінотіазолідин-4-онів 2a-b характерною $\epsilon$ наявність синглету у вузькому діапазоні 4.09-4.11 м.ч., який відповідає двом протонам метиленової групи в положенні 5 тіазолідинового циклу, що достовірно підтверджує проходження реакції циклізації та структуру цільових сполук.

У спектрах ПМР синтезованих 5-арил(гетерил) іденпохідних (3a-d та 4a-c) метиліденовий протон утворює синглет в діапазоні 7.64-7.75 м.ч., що свідчить про Z-конфігурацію 5-ариліденового фррагмента і відповідає відомим літературним даним для структурно подібних гетероциклічних систем [17].

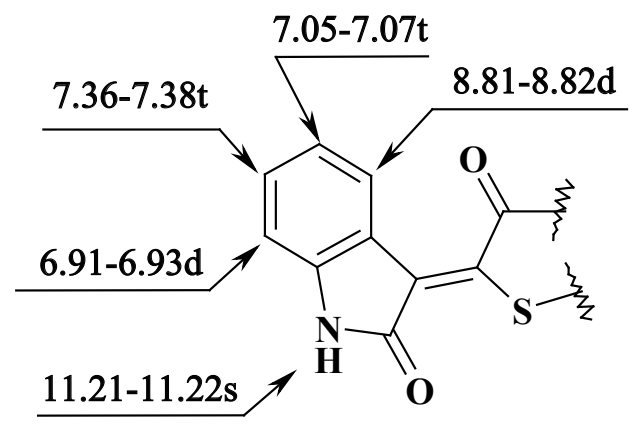

Сигнал $\mathrm{NH}$-протону в положенні 3 тіазолідинового циклу у спектрах ПМР 5-незаміщених похідних 2a-b проявляється при 12.28-12.33 м.ч., у вигляді синглету. Натомість для 5-іліденпохідних (сполуки 3a-d, 4a-c, 5a-b та 6a-b) зазначений протон резонує синглетом або широким синглетом у діапазоні 12,6013,10 м.ч., причому, його інтенсивність не завжди повністю відтворюється, що є характерним для зазначеного класу речовин.

Як відомо, для похідних 2-імінотіазолідин-4-ону характерна прототропна аміно-імінна таутомерія, причому в літературі наведено досить багато неоднозначних, зокрема і суперечливих, тверджень відносно положення рівноваги або переваги на користь однієї 3 таутомерних фрорм [18-20].

У нашому випадку, базуючись на даних спектрів ПМР, a caме за значенням хімзсуву сигналу $\mathrm{NH}$ протону в сторону слабкого магнітного поля, що знаходиться в області 12.28-13.10 м.ч. і є характерним для ендоциклічного атома Нітрогену в положенні 3 тіазолідинового циклу. Це дає можливість стверджувати про еребування досліджуваних 2-(1,3,4-тіадіазол-2-іл)іміно-тіазолідин-4-онів в розчинах у 2-іміноформі, що узгоджується 3 отриманими нами раніше результатами рентгеноструктурного аналізу для структурно споріднених оксадіазол-заміщених 2-імінотіазолідин-4-онів [21]. Крім того, незва-
Для 5-ізатиніліденпохідних 5a-b спостерігається характерний субспектр 5-незаміщеної ізатинової системи у вигляді двох дублетів при 6.91-6.93 м.ч. та 8.818.82 м.ч., а також двох триплетів при 7.05-7.07 м.ч. та 7.36-7.38 м.ч. Важливо відзначити, що сигнал протону в положенні 4 ізатинового фрагмента 5-ізатиніліден-2імінотіазолідин-4-онів суттєво зміщений в область слабкого магнітного поля, що можна пояснити впливом карбонільної групи в положенні 4 тіазолідинового циклу і, відповідно, утворенням Z-ізомеру.

3-(4-Нітрофеніл)-2-хлоропропен-1-іліденовий сррагмент (сполука 6b) утворює субспектр з двох дублетів при 8.01 м.ч. та 8.23 м.ч., що відповідають протонам п-нітрозаміщеного фенільного ядра, та двох синглетів при 7.65 м.ч. та 7.84 м.ч., утворених протонами метиліденових груп (-CH=).

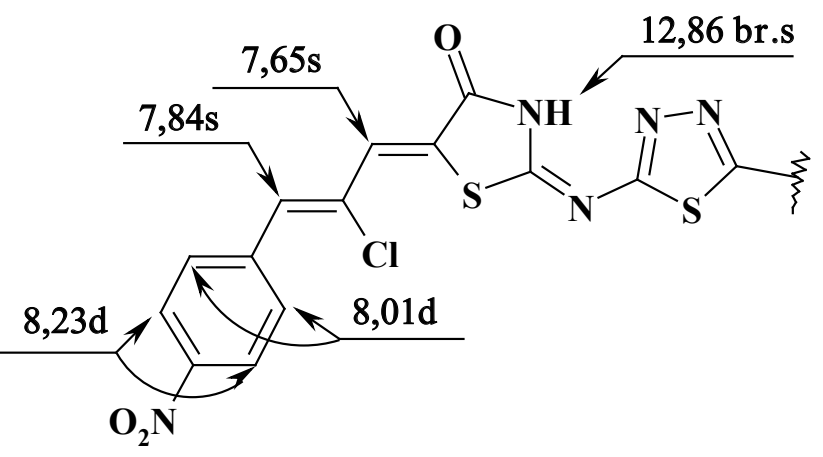

жаючи на не повністю відтворювану інтенсивність сигналу $\mathrm{NH}$-протону для більшості сполук, на спектрах ПМР не спостерігається інших сигналів або подвоєння наявних, які можна було б трактувати як можливі прототропні таутомерні перетворення в розчині.

Вивчення антитрипаносомної активності для 6-ти синтезованих сполук (2b, 3c, 3d, 4b, 4c та 5b) проводили на штамах Trypanosoma brucei gambiense (TBG). В результаті дослідження встановлено значення відсотків інгібування росту паразитів за рівнем фрлуоресценції Alamar Blue порівняно $з$ контролем для тестованих сполук у кожній 3 досліджуваних концентрацій (50, 10 та 1 мкг/ мл). Для сполук, які продемонстрували значну трипаноцидну активність в концентрації 10 мкг/мл (> 40-50\% інгібування росту), проводили обчислення значення $\mathrm{IC}_{50}$ (табл.) за дозозалежною кривою відсоткового росту паразитів від концентрації досліджуваних сполук (табл. 1).

На основі одержаних результатів дослідження антитрипаносомної активності встановлено, що 1,3,4-тіадіазол-заміщені 2-імінотіазолідин-4-они та їх 5-іліденпохідні володіють помірним трипаноцидним ефректом 3 діапазоном значень $\mathrm{IC}_{50}=7.3 \div 12.8$ мкM, за винятком сполук $\mathbf{2 b}$ та $\mathbf{4 c}$, які взагалі не проявили інгібуючий вплив на ріст паразитів. 
Синтез біологічно активних сполук

Synthesis of biologically active compounds

Таблиця 1. Антитрипаносомна активність синтезованих 2-(1,3,4-тіадіазол-2-іліміно)-тіазолідин-4-онів на штамі Trypanosoma brucei gambiense

\begin{tabular}{|c|c|c|c|c|c|c|}
\hline \multirow{2}{*}{ Сполука } & \multirow{2}{*}{$\operatorname{Ar}^{1}$} & \multirow{2}{*}{$\operatorname{Ar}(\mathrm{Het})$} & \multicolumn{2}{|c|}{$\mathrm{IC}_{50}$} & \multicolumn{2}{|c|}{$\mathrm{IC}_{50}$} \\
\hline & & & мкг/мл & SD & мкM & SD \\
\hline $2 b$ & $\mathrm{SCH}_{2} \mathrm{CH}=\mathrm{CH}_{2}$ & - & $>10$ & - & $>36,7$ & - \\
\hline $3 c$ & $\mathrm{SCH}_{2} \mathrm{CH}=\mathrm{CH}_{2}$ & $4-\mathrm{OH}-\mathrm{C}_{6} \mathrm{H}_{4}$ & 2,8 & 0,4 & 7,3 & 0,9 \\
\hline $3 d$ & $\mathrm{SCH}_{2} \mathrm{CH}=\mathrm{CH}_{2}$ & $4-\mathrm{CH}_{3} \mathrm{O}-\mathrm{C}_{6} \mathrm{H}_{4}$ & 3,9 & 0,3 & 10,1 & 0,6 \\
\hline $4 b$ & $\mathrm{SCH}_{2} \mathrm{CH}=\mathrm{CH}_{2}$ & тіофрен-2-іл & 4,2 & 0,2 & 11,4 & 0,6 \\
\hline $4 \mathrm{c}$ & $\mathrm{C}_{2} \mathrm{H}_{5}$ & піридин-3-іл & $>10$ & - & $>31,5$ & - \\
\hline $5 b$ & $\mathrm{SCH}_{2} \mathrm{CH}=\mathrm{CH}_{2}$ & 2-оксоіндол-3-іліден & 5,1 & 1,0 & 12,8 & 2,5 \\
\hline
\end{tabular}

\section{Експериментальна хімічна частина}

3 агальна методика синтезу $\mathrm{N}-(5-$ етил(алілсульфаніл)-1,3,4-тіадіазол-2-іл)заміщених 2-хлороацетамідів (1a-b).

У плоскодонну колбу поміщають 0,025 моль вихідного 2-аміно-1,3,4-тіадіазолу та еквімолярну кількість триетиламіну, додають 50 мл діоксану і обережно нагрівають до часткового розчинення вихідного аміну (розчин А). Окремо готують розчин 0,025 моль хлороацетилхлориду в 30 мл діоксану (розчин Б), який повільно, при постійному перемішуванні, додають до розчину А. Реакційну суміш витримують в термічній шафрі при температурі $\sim 95-100^{\circ} \mathrm{C}$ протягом 20 хв, після чого вміст колби повністю охолоджують, продукт реакції осаджують водою, відфрільтровують, промивають водою, висушують і перекристалізовують 3 ацетатної кислоти.

2-Хлоро-N-(5-етил-1,3,4-тіадіазол-2-іл)ацетамід (1a). Вихід 85 \%. Т.пл. 227-228 ${ }^{\circ} \mathrm{C}$. Знайдено, \%: N 20.68, S - 15.75. $\mathrm{C}_{6} \mathrm{H}_{8} \mathrm{CIN}_{3} \mathrm{OS}$. Вирахувано, \%: N 20.43, S - 15.59. ЯМP ${ }^{1} \mathrm{H}, \delta$, м.ч.: 1.30т (3Н, J = 7.5 Гц, $\left.\mathrm{CH}_{2} \underline{\mathrm{CH}}_{3}\right), 3.00$ кв $\left(2 \mathrm{H}, \mathrm{J}=7.5 \Gamma ц, \underline{\mathrm{CH}}_{2} \mathrm{CH}_{3}\right), 4.42 \mathrm{c}(2 \mathrm{H}$, $\left.\mathrm{ClCH}_{2} \mathrm{CO}\right), 12.79 \mathrm{c}(1 \mathrm{H}, \mathrm{CONH})$.

2-Хлоро-N-(5-алілсульфраніл-1,3,4-тіадіазол-2-іл) ацетамід (1b). Вихід 88 \%. Т.пл. 197-198 C. Знайдено, \%: N-17.12, S - 25.92. $\mathrm{C}_{7} \mathrm{H}_{8} \mathrm{ClN}_{3} \mathrm{OS}_{2}$. Вирахувано, \%: $\mathrm{N}-16.83, \mathrm{~S}-25.68$.

Загальна методика синтезу 5-незаміщених 2-(5-етил(алілсульфраніл)-1,3,4-тіадіазол-2-іл) імінотіазолідин-4-онів (2a-b).

У круглодонну колбу місткістю 250 мл поміщають 0,025 моль відповідного N-(1,3,4-тіадіазол-2-іл)заміщеного 2-хлороацетаміду (сполуки 1a або 1b), 0,05 моль амонію тіоціанату, додають 80 мл ацетону і нагрівають під зворотним холодильником протягом 5 год. Після повного охолодження реакційної суміші продукт реакції осаджують водою, відфільтровують, промивають водою, висушують і перекристалізовують 3 оцтової кислоти.

2-(5-Етил-1,3,4-тіадіазол-2-іліміно)тіазолідин-4он (2a). Вихід 70 \%. Т.пл. 211-212 ${ }^{\circ} \mathrm{C}$. Знайдено, \%: N - 24.43, S - 28.32. $\mathrm{C}_{7} \mathrm{H}_{8} \mathrm{~N}_{4} \mathrm{OS}_{2}$. Вирахувано, \%: N -
24.54, S - 28.09. ЯМР ${ }^{1} \mathrm{H}, \delta$, м.4.: 1.30т $(3 \mathrm{H}, \mathrm{J}=7.5$ Гц, $\left.\mathrm{CH}_{2} \mathrm{CH}_{3}\right), 3.01 \mathrm{kB}\left(2 \mathrm{H}, \mathrm{J}=7.5\right.$ Гц, $\left.\mathrm{CH}_{2} \mathrm{CH}_{3}\right), 4.09 \mathrm{c}(2 \mathrm{H}$, 5- $\mathrm{CH}_{2}$, тіазолідин), $12.28 \mathrm{c}(1 \mathrm{H}, \mathrm{NH}$, тіазолідин).

2-(5-Алілсульфраніл-1,3,4-тіадіазол-2-іліміно) тіазолідин-4-он (2b). Вихід 68 \%. Т.пл. 187-188 ${ }^{\circ} \mathrm{C}$. Знайдено, \%: N - 20.72, S - 35.54. $\mathrm{C}_{8} \mathrm{H}_{8} \mathrm{~N}_{4} \mathrm{OS}_{3}$. Вирахувано, \%: $\mathrm{N}-20.57, \mathrm{~S}-35.32$. ЯМР ${ }^{1} \mathrm{H}, \delta$, м.4.: 3.91д $\left(2 \mathrm{H}, \mathrm{J}=6.8\right.$ Гц, $\left.\mathrm{SCH}_{2}-\right), 4.11 \mathrm{c}\left(2 \mathrm{H}, 5-\mathrm{CH}_{2}\right.$, тіазолідин), 5.18д $\left(1 \mathrm{H}, \mathrm{J}=9.9\right.$ Гц, $\left.\mathrm{CH}=\mathrm{CH}_{2}\right), 5.32 д(1 \mathrm{H}, \mathrm{J}=16.5$ Гц, $\left.\mathrm{CH}=\underline{\mathrm{CH}}_{2}\right), 5.88-6.01 \mathrm{M}\left(1 \mathrm{H}, \underline{\mathrm{CH}}=\mathrm{CH}_{2}\right), 12.33 \mathrm{c}(1 \mathrm{H}, \mathrm{NH}$, тіазолідин).

Загальна методика синтезу 5-арил(гетерил)іліденпохідних 2-(5-етил(алілсульфаніл)-1,3,4-тіадіазол-2іл)імінотіазолідин-4-онів (3a-d, 4a-c).

Суміш 0,002 моль 2-(тіадіазол-2-іл)імінотіазолідин4-ону (2a або 2b), 0,002 моль безводного ацетату натрію та 0,0022 моль відповідного ароматичного альдегіду, тіофен-2-карбальдегіду або піридин-3карбальдегіду в 15 мл оцтової кислоти нагрівають протягом 5 год у колбі зі зворотним холодильником. Утворений осад відфільтровують, промивають послідовно оцтовою кислотою, водою та етанолом, висушують і перекристалізовують із суміші ДМФА - етанол (1:2).

5-(Z)-(4-Бромобензиліден)-2-(5-етил-1, 3, 4тіадіазол-2-іліміно)тіазолідин-4-он (3а). Вихід $70 \%$. Т.пл. 312-313 ${ }^{\circ} \mathrm{C}$. Знайдено, \%: N - 14.36, S - 16.45. $\mathrm{C}_{14} \mathrm{H}_{11} \mathrm{BrN}_{4} \mathrm{OS}_{2}$. Вирахувано, \%: $\mathrm{N}-14.17, \mathrm{~S}-16.22$. ЯMP ${ }^{1} \mathrm{H}, \delta$, м.4.: 1.31т (3H, J = 7.5 Гц, $\left.\mathrm{CH}_{2} \underline{\mathrm{CH}}_{3}\right), 3.03 \mathrm{~KB}$ $\left(2 \mathrm{H}, \mathrm{J}=7.5\right.$ Гц, $\left.\underline{\mathrm{CH}}_{2} \mathrm{CH}_{3}\right), 7.60 д$ (2H, J = 8.2 Гц, аром), $7.75 \mathrm{c}(1 \mathrm{H},-\mathrm{CH}=), 7.79$ д (2H, J = 8.2 Гц, аром), 12.92c (1Н, NH, тіазолідин).

5-(Z)-(4-Диметиламінобензиліден)-2-(5-етил1,3,4-тіадіазол-2-іліміно)-тіазолідин-4-он (3b). Вихід 74 \%. Т.пл. 271-272 C. Знайдено, \%: N - 19.72, S 18.03. $\mathrm{C}_{16} \mathrm{H}_{17} \mathrm{~N}_{5} \mathrm{OS}_{2}$. Вирахувано, \%: N - 19.48, S 17.84. ЯМР ${ }^{1} \mathrm{H}, \delta$, м.ч.: $1.31 \mathrm{~T}\left(3 \mathrm{H}, \mathrm{J}=7.5\right.$ Гц, $\left.\mathrm{CH}_{2} \mathrm{CH}_{3}\right)$, $3.02 \mathrm{c}\left(8 \mathrm{H}, \mathrm{CH}_{2} \mathrm{CH}_{3}, \mathrm{~N}\left(\mathrm{CH}_{3}\right)_{2}\right), 6.85 \mathrm{~g}(2 \mathrm{H}, \mathrm{J}=8.5$ Гц, аром), 7.48д (2H, J = 8.6 Гц, аром), 7.65с (1H, $-\mathrm{CH}=)$, 12.60с (1Н, NH, тіазолідин).

5-(Z)-(4-Гідроксибензиліден)-2-(5-алілсульфраніл1,3,4-тіадіазол-2-іліміно)-тіазолідин-4-он (3с). Вихід

ISSN 2312-0967. Фармацевтичний часопис. 2017. № 3 
81 \%. Т.пл. 293-294 ${ }^{\circ} \mathrm{C}$. Знайдено, \%: N - 15.07, S 25.79. $\mathrm{C}_{15} \mathrm{H}_{12} \mathrm{~N}_{4} \mathrm{O}_{2} \mathrm{~S}_{3}$. Вирахувано, \%: $\mathrm{N}-14.88, \mathrm{~S}-$ 25.55. ЯМР ${ }^{1} \mathrm{H}, \delta$, м.ч.: 3.91д $\left(2 \mathrm{H}, J=5.4\right.$ Гц, $\left.\mathrm{SCH}_{2}-\right)$, 5.19д $\left(1 \mathrm{H}, \mathrm{J}=9.8\right.$ Гц, $\left.\mathrm{CH}=\underline{\mathrm{CH}}_{2}\right), 5.34 д(1 \mathrm{H}, \mathrm{J}=16.5$ Гц, $\left.\mathrm{CH}=\underline{\mathrm{CH}}_{2}\right), 5.94-6.04 \mathrm{M}\left(1 \mathrm{H}, \underline{\mathrm{CH}}=\mathrm{CH}_{2}\right), 6.92 д(2 \mathrm{H}, \mathrm{J}=6.9$ Гц, аром), 7.46д (2H, J = 7.3 Гц, аром), 7.64с $(1 \mathrm{H},-$ $\mathrm{CH}=), 10.16 \mathrm{c}(1 \mathrm{H}, \mathrm{OH}), 12.63 \mathrm{c}(1 \mathrm{H}, \mathrm{NH}$, тіазолідин $)$.

5-(Z)-(4-Метоксибензиліден)-2-(5-алілсульфраніл1,3,4-тіадіазол-2-іліміно)-тіазолідин-4-он (3d). Вихід 74 \%. Т.пл. $271-272$ C. Знайдено, \%: N - 19.72, S 18.03. $\mathrm{C}_{16} \mathrm{H}_{17} \mathrm{~N}_{5} \mathrm{OS}_{2}$. Вирахувано, \%: $\mathrm{N}-19.48, \mathrm{~S}-$ 17.84. ЯМР ${ }^{1} \mathrm{H}, \delta$, м.ч.: $3.84 \mathrm{c}\left(3 \mathrm{H}, \mathrm{OCH}_{3}\right), 3.94 д(2 \mathrm{H}, \mathrm{J}$ $=6.6$ Гц, $\left.\mathrm{SCH}_{2}-\right), 5.20 д\left(1 \mathrm{H}, \mathrm{J}=9.5\right.$ Гц, $\left.\mathrm{CH}=\underline{\mathrm{CH}}_{2}\right), 5.34 д$ $\left(1 \mathrm{H}, \mathrm{J}=17.0\right.$ Гц, $\left.\mathrm{CH}=\underline{\mathrm{CH}}_{2}\right), 5.91-6.04 \mathrm{M}\left(1 \mathrm{H}, \underline{\mathrm{CH}}=\mathrm{CH}_{2}\right)$, $7.16 д$ (2H, J = 7.9 Гц, аром), 7.64д (2H, J = 8.1 Гц, аром), 7.75c (1H, $-\mathrm{CH}=), 12.87 \mathrm{c}(1 \mathrm{H}, \mathrm{NH}$, тіазолідин).

5-(Z)-(Тіофен-2-ілметиліден)-2-(5-етил-1, 3, 4тіадіазол-2-іліміно)тіазолідин-4-он (4a). Вихід 80 \%. Т.пл. 264-265 С. Знайдено, \%: N - 17.51, S - 30.04. $\mathrm{C}_{12} \mathrm{H}_{10} \mathrm{~N}_{4} \mathrm{OS}_{3}$. Вирахувано, \%: N - 17.38, S - 29.83.

5-(Z)-(Тіофрен-2-ілметиліден)-2-(5-алілсульфраніл1,3,4-тіадіазол-2-іліміно)-тіазолідин-4-он (4b). Вихід 77 \%. Т.пл. 297-298 С. Знайдено, \%: N - 15.56, S 35.17. $\mathrm{C}_{13} \mathrm{H}_{10} \mathrm{~N}_{4} \mathrm{OS}_{4}$. Вирахувано, \%: $\mathrm{N}-15.29$, S 34.99. ЯМР ${ }^{1} \mathrm{H}, \delta$, М.ч.: 3.95д $\left(2 \mathrm{H}, J=6.8\right.$ Гц, $\left.\mathrm{SCH}_{2}-\right)$, $5.20 д\left(1 \mathrm{H}, \mathrm{J}=9.8\right.$ Гц, $\left.\mathrm{CH}=\underline{\mathrm{CH}}_{2}\right), 5.35 д(1 \mathrm{H}, \mathrm{J}=16.3$ Гц, $\left.\mathrm{CH}=\underline{\mathrm{CH}}_{2}\right), 5.90-6.05 \mathrm{M}\left(1 \mathrm{H}, \underline{\mathrm{CH}}=\mathrm{CH}_{2}\right), 7.31 \mathrm{~T}(1 \mathrm{H}, \mathrm{J}=4.4$ Гц, тіофен), 7.73c $(1 \mathrm{H},-\mathrm{CH}=), 8.03-8.06 \mathrm{M}(2 \mathrm{H}$, тіофрен), 12.92с (1Н, NH, тіазолідин).

5-(Z)-(Піридин-3-ілметиліден)-2-(5-етил-1,3,4тіадіазол-2-іліміно)тіазолідин-4-он (4c). Вихід $75 \%$ Т.пл. 251-252 C. Знайдено, \%: N - 22.31, S - 20.38. $\mathrm{C}_{13} \mathrm{H}_{11} \mathrm{~N}_{5} \mathrm{OS}_{2}$. Вирахувано, \%: N - 22.07, S - 20.20. ЯMP ${ }^{1} \mathrm{H}, \delta$, м.ч.: 1.37т (3H, J = 7.4 Гц, $\left.\mathrm{CH}_{2} \underline{\mathrm{CH}}_{3}\right), 3.02 \mathrm{\kappa в}$ $\left(2 \mathrm{H}, \mathrm{J}=7.2\right.$ Гц, $\left.\mathrm{CH}_{2} \mathrm{CH}_{3}\right), 7.54 \mathrm{~T}(1 \mathrm{H}, \mathrm{J}=7.1$ Гц, піридин), 7.74c (1Н, -CH=), 7.97д (1Н, J = 6.9 Гц, піридин), 8.57д (1Н, J = 7.5 Гц, піридин), 8.80с (1Н, піридин), 12.88шс (1H, NH, тіазолідин).

Загальна методика синтезу 5-ізатиніліден- (5ab) та 5-(3-феніл-2-пропен-1-іліден)похідних (6a-b) 2-(5-етил(алілсульфаніл)-1,3,4-тіадіазол-2-іл) імінотіазолідин-4-онів.

Суміш 0,002 моль відповідного 2-(тіадіазол-2-іл) імінотіазолідин-4-ону (2a або 2b), 0,0022 моль ізатину, коричного альдегіду або циміналю та 0,002 моль ацетату натрію поміщають в круглодонну колбу, додають 15 мл оцтової кислоти і кип'ятять зі зворотним холодильником протягом 5 год. Осад, який утворився, відфільтровують, промивають послідовно оцтовою кислотою, водою та етанолом, висушують і перекристалізовують з суміші ДМФА - етанол (1:2).
5-(Z)-(2-Оксо-2, 3-дигідроіндол-3-іліден)-2-(5етил-1,3,4-тіадіазол-2-іліміно)-тіазолідин-4-он (5а). Вихід 87 \%. Т.пл. $>320$ C. Знайдено, \%: N - 19.82, S - 18.17. $\mathrm{C}_{15} \mathrm{H}_{11} \mathrm{~N}_{5} \mathrm{O}_{2} \mathrm{~S}_{2}$. Вирахувано, \%: N-19.59, S 17.94. ЯМР ${ }^{1} \mathrm{H}, \delta$, М.ч.: $1.32 \mathrm{~T}\left(3 \mathrm{H}, \mathrm{J}=7.1\right.$ Гц, $\left.\mathrm{CH}_{2} \mathrm{CH}_{3}\right)$, $3.04 \mathrm{Kв}\left(2 \mathrm{H}, \mathrm{J}=7.3\right.$ Гц, $\left.\mathrm{CH}_{2} \mathrm{CH}_{3}\right), 6.93 д(1 \mathrm{H}, J=7.6$ Гц, ізатин), 7.07т (1Н, J = 7.8 Гц, ізатин), 7.38т (1H, J = 7.5 Гц, ізатин), 8.82д (1Н, J = 7.2 Гц, ізатин), 11.22с $(1 \mathrm{H}$, $\mathrm{NH}$, ізатин), $13.05 \mathrm{c}(1 \mathrm{H}, \mathrm{NH}$, тіазолідин).

5-(Z)-(2-Оксо-2,3-дигідроіндол-3-іліден)-2-(5алілсульфраніл-1,3,4-тіадіазол-2-іліміно)тіазолідин4-он (5b). Вихід 84 \%. Т.пл. 294-295 С. Знайдено, \%: $\mathrm{N}-17.67, \mathrm{~S}-24.13 . \mathrm{C}_{16} \mathrm{H}_{11} \mathrm{~N}_{5} \mathrm{O}_{2} \mathrm{~S}_{3}$. Вирахувано, \%: N - 17.44, S - 23.96. ЯМP ${ }^{1} \mathrm{H}, \delta$, м.4.: 3.94д $(2 \mathrm{H}, \mathrm{J}=6.6$ Гц, $\left.\mathrm{SCH}_{2}-\right), 5.21 д\left(1 \mathrm{H}, \mathrm{J}=9.8\right.$ Гц, $\left.\mathrm{CH}=\mathrm{CH}_{2}\right), 5.35 д(1 \mathrm{H}$, $\left.\mathrm{J}=16.6 \mathrm{~Hz}, \mathrm{CH}=\underline{\mathrm{CH}}_{2}\right), 5.90-6.04 \mathrm{M}\left(1 \mathrm{H}, \underline{\mathrm{CH}}=\mathrm{CH}_{2}\right), 6.91 д$ $(1 \mathrm{H}, \mathrm{J}=7.7$ Гц, ізатин $), 7.05 \mathrm{~T}(1 \mathrm{H}, \mathrm{J}=7.7$ Гц, ізатин $)$, 7.36т (1H, J = 7.4 Гц, ізатин), 8.81д (1Н, J = 7.4 Гц, ізатин), 11.21c (1H, NH, ізатин), 13.10с $(1 \mathrm{H}, \mathrm{NH}$, тіазолідин).

5-(Z)-(3-Феніл-2-пропен-1-іліден)-2-(5-етил-1,3,4тіадіазол-2-іліміно)-тіазолідин-4-он (6а). Вихід 76 \%. Т.пл. 258-259 С. Знайдено, \%: N - 16.51, S - 18.95. $\mathrm{C}_{16} \mathrm{H}_{14} \mathrm{~N}_{4} \mathrm{OS}_{2}$. Вирахувано, \%: N - 16.36, S - 18.73.

5-(Z)-[3-(4-Нітрофреніл)-2-хлоропропен-1-іліден)]2-(5-етил-1,3,4-тіадіазол-2-іліміно)тіазолідин-4-он (6b). Вихід 76 \%. Т.пл. 319-320 ㄷ․ Знайдено, \%: N 16.88, S - 15.43. $\mathrm{C}_{16} \mathrm{H}_{12} \mathrm{ClN}_{5} \mathrm{O}_{3} \mathrm{~S}$. Вирахувано, \%: N 16.60, S - 15.20. ЯMP ${ }^{12} \mathrm{H}, \delta$, М.4.: 1.31т (3H, J = 7.4 Гц, $\left.\mathrm{CH}_{2} \underline{\mathrm{CH}}_{3}\right), 3.02 \mathrm{Kв}\left(2 \mathrm{H}, \mathrm{J}=7.3\right.$ Гц, $\left.\underline{\mathrm{CH}}_{2} \mathrm{CH}_{3}\right), 7.65 \mathrm{c}(1 \mathrm{H}$, $-\mathrm{CH}=), 7.84 \mathrm{c}(1 \mathrm{H},-\mathrm{CH}=), 8.01 д(2 \mathrm{H}, \mathrm{J}=8.3$ Гц, аром), 8.23д (2H, J = 8.4 Гц, аром), 12.86шс $(1 \mathrm{H}, \mathrm{NH}$, тіазолідин).

Висновки. 1. Шляхом ацилювання вихідних 5-етил- та 5-алілсульфраніл-2-аміно-1,3,4-тіадіазолів хлороацетилхлоридом одержано відповідні $N$-заміщені 2-хлороацетаміди, які успішно використано в реакції циклізації під дією амонію тіоціанату для синтезу похідних 2-імінотіазолідин-4-ону 3 1,3,4-тіадіазольним фррагментом у положенні 2.

2. Проведено подальшу хімічну модифікацію отриманих 2-(1,3,4-тіадіазол-2-іл)імінотіазолідин-4-онів в умовах реакції Кньовенагеля 3 різноманітними арил(гетерил)карбальдегідами, похідними ізатину та коричного альдегіду з утворенням серій відповідних 5-іліденпохідних.

3. За результатами дослідження антитрипаносомної активності ідентифріковано чотири сполуки, що в мікромолярних концентраціях володіли суттєвим трипаноцидним ефектом відносно штаму Trypanosoma brucei gambiense. 
Синтез біологічно активних сполук

Synthesis of biologically active compounds

СИНТЕЗ И ИССЛЕДОВАНИЕ АНТИТРИПАНОСОМНОЙ АКТИВНОСТИ НОВЫХ 5-ИЛИДЕН-2-(1,3,4ТИАДИАЗОЛ-2-ИЛ)ИМИНОТИАЗОЛИДИН-4-ОНОВ

\author{
М. И. Лелюх ${ }^{1}$, Б. С. Зименковский ${ }^{1}$, И. Л. Демчук ${ }^{1}$ Филипп Грелье ${ }^{2}$ Р. Б. Лесык ${ }^{1}$ \\ Львовский национальный медицинский университет имени Данила Галицкого ${ }^{1}$ \\ Национальный музей истории природы, ${ }^{2}$ Париж, Франция \\ lelyukh.m@gmail.com \\ dr_r_lesyk@org.Iviv.net
}

Цель роботы. На основе реакций гетероциклизации и Кневенагеля осуществить синтез новых тиадиазоло-2иминотиазолидин-4-онов и их 5-илиденпроизводных для скрининга антитрипаносомной активности.

Материалы и методы. Органический синтез, спектроскопия ЯМР, элементный анализ, фрармакологический скрининг.

Результаты и обсуждение. Циклизацией N-(1,3,4-тиадиазол-2-ил)замещенных 2-хлороацетамидов под действием аммония тиоцианата в среде ацетона синтезировано группу новых производных 2-иминотиазолидин-4-она. Наличие метиленактивной группы в положение 5 тиазолидинового цикла полученных 2-(1,3,4-тиадиазол-2-ил) иминотиазолидин-4-онов позволило провести их дальнейшую химическую модисрикацию в условиях реакции Кнёвенагеля с разными арил(гетерил)карбальдегидами, изатином или производными коричного альдегида с образованием серий 5-арил(гетерил)илиден- и 5-изатин(3-френилпропен)илиденпроизводных как потенциальных трипаноцидных агентов. Строение синтезированных соединений подтверждено элементным анализом и спектроскопией ПМР.

Выводы. Результаты скрининга антитрипаносомной активности in vitro синтезированных соединений на штамме Trypanosoma brucei gambiense (TBG) позволили идентифицировать четыре высокоактивные соединения, которие со значениями $I_{50}$ в пределах 7,3-12,8 мкМ обладали существенным трипаноцидным эффектом.

Ключевые слова: 2-иминотиазолидин-4-оны; 1,3,4-тиадиазолы; реакция гетероциклизации; амино-иминная таутомерия; конденсация Кнёвенагеля; E/Z-изомерия; спектральные характеристики; антитрипаносомная активность.

\title{
SYNTHESIS AND ANTITRYPANOSOMAL ACTIVITY INVESTIGATION OF NOVEL 5-YLIDENE-2-(1,3,4- THIADIAZOL-2-YL)IMINOTHIAZOLIDIN-4-ONES
}

\author{
M. I. Lelyukh¹, B. S. Zimenkovsky¹, I. L. Demchuk ${ }^{1}$, Philippe Grellier ${ }^{2}$, R. B. Lesyk ${ }^{1}$ \\ Danylo Halytsky Lviv National Medical University ${ }^{1}$ \\ National Museum of Natural History, Paris², France \\ lelyukh.m@gmail.com \\ dr_r_lesyk@org.Iviv.net
}

The aim of work. Synthesizing the new thiadiazolo-2-iminothiazolidin-4-ones and their 5-arylidene derivatives based on the heterocyclization reaction and Knoevenagel condensation and study their antitrypanosomal activity.

Materials and Methods. Organic synthesis, NMR spectroscopy, elemental analysis, pharmacological screening.

Results and Discussion. Following the cyclization reaction of $N$-(1,3,4-thiadiazol-2-yl)substituted 2-chloroacetamides with ammonium thiocyanate in dry acetone the corresponding 2-imino-4-thiazolidinone derivatives have been obtained. Further chemical modification of synthesized methylene active 2-(1,3,4-thiadiazol-2-yl)imino-4-thiazolidinones was performed via Knoevenagel condensation with various aromatic or heterocyclic aldehydes, isatin or cinnamic aldehyde derivatives have yielded a series of 5-aryl(heteryl)ylidene- and 5-isatin(3-phenylpropene)ylidene derivatives as potential antitrypanosomal agents. The structure of obtained compounds was confirmed by NMR spectroscopy and elemental analysis.

Conclusions. The results of in vitro screening of antitrypanosomal activity against Trypanosoma brucei gambiense (TBG) allowed us to identify four highly active compounds which owned essential trypanocidal effect with a range of values $I_{50}$ within 7.3-12.8 $\mu \mathrm{M}$.

Key words: 2-iminothiazolidin-4-ones; 1,3,4-thiadiazoles; heterocyclization reaction; amino-imino tautomerism; Knoevenagel condensation; ElZ-isomerism; spectral data; antitrypanosomal activity.

ISSN 2312-0967. Фармацевтичний часопис. 2017. № 3 


\section{Список літератури}

1. Synthesis, in vitro anticancer and antioxidant activity of thiadiazole substituted thiazolidin-4-ones / A. Joseph, C. S. Shah, S. S. Kumar [et al.] // Acta Pharm. - 2013. Vol. 63. - P. 397-408.

2. Synthesis, in vitro evaluation, and molecular docking studies of azetidinones and thiazolidinones of 2-amino5-cyclopropyl-1,3,4-thiadiazole as antibacterial agents / H. atel, L. Mishra, M. Noolvi [et al.] // Arch. Pharm. - 2014. - Vol. 347. - P. 668-684.

3. Sahu R. Thiazolidinone based 2,5-disubstituted-1,3,4thiadiazole: Synthesis and antimicrobial evaluation / R. Sahu, S. Tiwari, G. Kalyani // Int. J. Pharm. Pharm. Sci. - 2013. - Vol. 5, Iss. 1. - P. 290-291.

4. Synthesis and antipsychotic and anticonvulsant activity of some new substituted oxa/thiadiazolylazetidinonyl/thiazolidinonylcarbazoles / H. Kaur, S. Kumar, P. Vishwakarma [et al.] // Eur. J. Med. Chem. - 2010. - Vol. 45. - P. 27772783.

5. Thiadiazole derivatives as potential anticonvulsant agents / P. Mullick, S. A. Khan, S. Verma [et al.] // Bull. Kor. Chem. Soc. - 2011. - Vol. 32, Iss. 3. - P. 1011-1016.

6. 2-Heteroarylimino-5-arylidene-4-thiazolidinones as a new class of non-nucleoside inhibitors of HCV NS5B polymerase / I. Kucukguzel, G. Satilmis, K. R. Gurukumar [et al.] // Eur. J. Med. Chem. - 2013. - Vol. 69. - P. 931-941.

7. Trotsko N. Cyclization of thiosemicarbazide derivatives of 5-arylidene-2,4-dioxothiazolidine-3-acetic acids to 1,3,4-thiadiazoles and their pharmacological properties / N. Trotsko, M. Dobosz, E. Jagiello-Wojtowicz // Acta Pol. Pharm. - 2007. - Vol. 64, No. 3. - P. 227-231.

8. Synthesis, hypoglycemic and hypolipidemic activities of novel thiazolidinedione derivatives containing thiazole/triazole/oxadiazole ring / A. K. M. Iqbal, A. Y. Khan, M. B. Kalashetti [et al.] // Eur. J. Med. Chem. - 2012. - Vol. 53. - P. 308-315.

9. 5-Nitroimidazole-based 1,3,4-thiadiazoles: heterocyclic analogs of metronidazole as anti-helicobacter pylori agents / M. H. Moshafi, M. Sorkhi, S. Emami [et al.] // Arch. Pharm. - 2011. - Vol. 344, Iss. 3. - P. 178-183.

10. Synthesis and antitumor-evaluation of 1,3,4-thiadiazole-containing benzisoselenazolone derivatives / Z. Luo, B. Chen, S. He [et al.] // Bioorg. Med. Chem. Lett. - 2012. - Vol. 22. - P. 3191-3193.

11. Synthesis and biological activity of 2-(bis $((1,3,4-$ oxadiazolyl/1,3,4-thiadiazolyl)methylthio)methylene)malo- nonitriles / V. Padmavathi, G. D. Reddy, S. N. Reddy [et al.] // Eur. J. Med. Chem. - 2011. - Vol. 46. - P. 1367-1373.

12. Рубцов М. В. Синтетические химико-фрармацевтические препараты (справочник) / М. В. Рубцов, А. Г. Байчиков. - Москва : Медицина, 1971. - С. 127.

13. Design, synthesis, and docking studies of new 1,3,4-thiadiazole-2-thione derivatives with carbonic anhydrase inhibitory activity / M. K. Abdel-Hamid, A. A. AbdelHafez, N. A. El-Koussi [et al.] // Bioorg. Med. Chem. - 2007. - Vol. 15. - P. 6975-6984.

14. Raz B. The Alamar Blue asssay to determine drug sensitivity of African trypanosomes (T. b. rhodesiense, T. b. gambiense) in vitro / B. Raz, M. Iten, Y. Grether-Buhler // Acta. Trop. - 1997. - Vol. 68. - P. 139-147.

15. Остап'юк Ю. В. а-Функціоналізовані тіоціанати реагенти для синтезу гетероциклів: автореср. дис. на здобуття наук. ступеня канд. хім. наук: спец. 02.00.03 «Органічна хімія» / Ю. В. Остап'юк. - Львів, 2008. - 20 с. 16. Матійчук В. С. Арил- і бензилзаміщені гетероцикли на основі реагентів. одержаних 3 використанням арендіазонієвих солей: автореф. дис. на здобуття наук. ступеня д-ра. хім. наук : спец. 02.00 .03 «Органічна хімія» / В. С. Матійчук. - Львів, 2014. - 46 с.

17. Попов-Пергал К. Конденсация 2,4-тетрагидро-1,3тиазола с ароматическими альдегидами / К. ПоповПергал, Ж. Чекович, М. Пергал // ЖОрХ. - 1994. - Т. 61, № 9. - С. 2112-2116.

18. Синтез гетероциклов на основе анионарилирования непредельных соединений / Н. Д. Обушак, В. С. Матийчук, Н. И. Ганущак, Ю. Э. Бурлак // ХГС. - 1998. - №4. - С. 555-559.

19. Исследование реакционной способности и таутомерии азолидинов. XXIV. Прототропная таутомерия и кислотно-основные свойства 2-амино- ${ }^{2}$-тиазолин-4-она / С. М. Рамш, А. И. Гинак, Н. А. Сморыго [и др.] // ЖОрХ. - 1978. - T. XIV, № 6. - C. 1327-1332.

20. Comrie A. M. Tautomerism of 2-iminothiazolin-4-ones and 2-amino-2-thiazolin-4-ones / A. M. Comrie // J. Chem. Soc. - 1964. - № 9. - P. 3478-3480.

21. Синтез та вивчення протипухлинної активності 5-іліденпохідних 2-(5-арил-1,3,4-оксадіазол-2-іл) імінотіазолідин-4-онів / М. І. Лелюх, Б. С. Зіменковський, І. Л. Демчук // Клінічна фрармація, фрармакотерапія та медична стандартизація - 2015. - №3-4 (27-28). C. $176-185$.

\section{References}

1. Joseph A, Shah CS, Kumar SS, Alex AT, Maliyakkal N, Moorkoth S, et al. Synthesis, in vitro anticancer and antioxidant activity of thiadiazole substituted thiazolidin-4-ones. Acta Pharm. 2013;63: 397-408. Available from: [Accepted May 13, 2013].

2. Patel H, Mishra L, Noolvi $M$, Karpoormath $R$, Cameotra SS. Synthesis, in vitro evaluation, and molecular docking studies of azetidinones and thiazolidinones of 2-amino-5-cyclopropyl-1,3,4-thiadiazole as antibacterial agents. Arch Pharm. 2014;347: 668-84.

3. Sahu R, Tiwari S, Kalyani G. Thiazolidinone based 2,5-di-

substituted-1,3,4-thiadiazole: Synthesis and antimicrobial evaluation. Int J Pharm Pharm Sci. 2013;5(1): 290-1.

4. Kaur H, Kumar S, Vishwakarma P, Sharma M, Saxena KK, Kumar A. Synthesis and antipsychotic and anticonvulsant activity of some new substituted oxa/thiadiazolylazetidinonyl/thiazolidinonylcarbazoles. Eur. J. Med. Chem. 2010;45: 2777-83.

5. Mullick P, Khan SA, Verma S, Alam O. Thiadiazole derivatives as potential anticonvulsant agents. Bull. Kor Chem Soc. 2011;32(3): 1011-16.

6. Kucukguzel I, Satilmis G, Gurukumar KR, Basu A, Ta-

ISSN 2312-0967. Pharmaceutical review. 2017. № 3 
Синтез біологічно активних сполук Synthesis of biologically active compounds

$\operatorname{tar}$ E, Nichols DB, et al. 2-Heteroarylimino-5-arylidene4-thiazolidinones as a new class of non-nucleoside inhibitors of HCV NS5B polymerase. Eur J Med Chem 2013; 69: 931-941. Available from: [Accepted 31 August 2013].

7. Trotsko N, Dobosz M, Jagiello-Wojtowicz E. Cyclization of thiosemicarbazide derivatives of 5-arylidene-2,4-dioxothiazolidine-3-acetic acids to 1,3,4-thiadiazoles and their pharmacological properties. Acta Pol Pharm. 2007;64: 22731.

8. Iqbal AKM, Khan AY, Kalashetti MB, Belavagi NS, Gong Y-D, Khazi IAM. Synthesis, hypoglycemic and hypolipidemic activities of novel thiazolidinedione derivatives containing thiazole/triazole/oxadiazole ring. Eur. J Med Chem. 2012;53: 308-15.

9. Moshafi MH, Sorkhi M, Emami S, Nakhjiri M, YahyaMeymandi A, Negahbani AS, et al. 5-Nitroimidazole-based 1,3,4-thiadiazoles: heterocyclic analogs of metronidazole as anti-helicobacter pylori agents. Arch Pharm 2011; 344(3): 178-183. Available from: [Accepted March 22, 2010]. 10. Luo Z, Chen B, He S, Shi Y, Liu Y, Li C. Synthesis and antitumor-evaluation of 1,3,4-thiadiazole-containing benzisoselenazolone derivatives. Bioorg Med Chem Lett. 2012;22: 3191-93.

11. Padmavathi V, Reddy GD, Reddy SN, Mahesh K. Synthesis and biological activity of 2-(bis ((1,3,4oxadiazolyl/1,3,4-thiadiazolyl)methylthio)methylene)-malononitriles. Eur J Med Chem. 2011;46: 1367-73.

12. Rubtsov MV, Baychykov AG. Synthetic chemical-pharmaceutical drugs (directory). [Синтетические химикосрармацевтические препараты (справочник)] Moscow: Medicine; 1971. Russian.

13. Abdel-Hamid MK, Abdel-Hafez AA, El-Koussi NA, Mahfouz NM, Innocenti A, Supuran CT. Design, synthesis, and docking studies of new 1,3,4-thiadiazole-2-thione derivatives with carbonic anhydrase inhibitory activity. Bioorg Med Chem. 2007;15: 6975-84.

14. Raz B, Iten M, Grether-Buhler Y. The Alamar Blue asssay to determine drug sensitivity of African trypanosomes (T. b. rhodesiense, T. b. gambiense) in vitro. Acta Trop. 1997;68; 139-47.

15. Ostapiuk YV. a-Functionalized thiocyanates - the reagents for syntheses of heterocycles [dissertation]. Lviv; 2008.

16. Matiychuk VS. Aryl- and benzyl- substituted heterocycles based on the reagents obtained with arenediazonium salts utilization [dissertation]. Lviv; 2015. Ukrainian.

17. Perhal-Popov K, Chekovych J, Perhal M. [Condensation of 2,4-tetrahydro-1,3-tyazole with aromatic aldehydes]. Zhurnal orhanycheskoy khimii. 1994;61(9): 2112-16. Russian.

18. Obushak ND, Matiychuk VS, Ganushchak NI, Burlak YuYe. [Synthesis of heterocycles on the basis of anion arylatied products of unsaturated-compounds]. Khimia heterocyklycheskyh soedynenyi. 1998;4: 555-9. Russian.

19. Ramsh SM, Ginak Al, Smorygo NA. [Investigation of the reactivity and tautomerism of azolidines. XXIV. Prototrophic tautomerism and acid-base properties]. Zhurnal orhanycheskoy khimii. 1978;XIV(6): 1327-32. Russian.

20. Comrie AM. Tautomerism of 2-iminothiazolin-4-ones and 2-amino-2-thiazolin-4-ones. J Chem Soc. 1964;9: 3478-80.

21. Lelyukh MI, Zimenkovsky BS, Demchuk IL, Gzella A, Lesyk RB. [Synthesis and antitumor evaluation of 5-ylidene derivatives 2-(5-aryl-1,3,4-oxadiazole-2-yl)iminothiazolidin4-ones]. Klinichna farmatsiia, farmakoterapiia ta medychna standartyzatsiia. 2015;3-4(27-28): 175-85.

Отримано 03.07.2017 